\title{
PEMENTASAN TEATER INDONESIA 2001-2005 (Analisis Rubrik Teater Majalah Tempo)
}

\author{
Nurhadi \\ Pendidikan Bahasa dan Sastra Indonesia \\ FBS Universitas Negeri Yogyakarta \\ e-mail:nurhadi2@yahoo.com
}

\begin{abstract}
This article describes titles of drama scripts or theatre performances in Indonesia reviewed in Tempo in 2001-2005. The data resources were review articles on theatres in the magazine recorded in a compact disc. The data were collected by sorting all the articles, categorizing them based on the problems, reading them carefully, and making notes on them. The data were analyzed using the descriptive qualitative technique. The findings showed that theatre performances in Indonesia reviewed in Tempo in 2001-2005 included: 11 foreign scripts, 7 translation scripts, 8 adaptation scripts, 29 purely Indonesian scripts, 2 Javanese scripts, and 7 articles on theatres. The number of foreign, translation, and adaptation scripts was 26. This number was almost the same as that of purely Indonesian scripts (and Javanese scripts) which was 31, so that the ratio was 26:31. The findings showed that Tempo, in terms of its theatre orientation, reviewed domestic and foreign theatres equally.
\end{abstract}

Keywords: theatre performance, theatre column, review, Tempo magazine.

\section{A. PENDAhuluan}

Perkembangan drama dan teater dimulai sejak masa awal perkembangannya pada akhir abad XIX hingga masa kontemporer. Sampai kini perkembangannya terus berlangsung. Berbeda dengan perkembangan sejarah sastra Indonesia, perkembangan drama dan teater Indonesia jarang dikaji banyak peneliti. Apalagi terhadap perkembangan drama dan teater yang mutakhir. Dalam realitasnya, banyak pementasan teater di berbagai kota dan juga banyak ulasan-ulasan berupa resensi maupun berita-berita yang menginformasikan pementasan teater ataupun ulasan buku-buku drama di berbagai media cetak. Meski begitu, hal-hal tersebut masih bersifat berserak dan sporadis.

Untuk mengatasi hal tersebut, diperlukan usaha pendokumentasian ulasan dan berita pementasan tersebut. Dokumen tersebut merupakan salah satu bentuk resepsi masyarakat terhadap perkembangan drama dan teater. Dari dokumen-dokumen itu terungkap berbagai hal yang berkaitan dengan pementasan teater tersebut, juga termuat penilaian atau apresiasi penulisnya terhadap teater itu dalam konteks kesejarahannya, mengingat suatu naskah drama terkadang dipentaskan ulang dalam periode yang berbeda sehingga memungkinkan adanya resepsi yang berbeda pula.

Peliputan wartawan media cetak atau peresensi atas pementasan teater (dan drama) juga merupakan salah satu kriteria besar kecilnya mutu pementasan tersebut, paling tidak menurut standar mutu masing-masing media cetak. Hanya pementasan yang bermutulah yang layak dimuat mengingat keterbatasan kolom untuk bidang budaya apalagi perteateran. Dengan begitu, akan didapatkan sejumlah informasi perkembangan drama dan teater Indonesia sebagai salah satu bentuk resepsi sastra melalui media cetak.

Artikel penelitian ini lebih difokuskan pada perkembangan drama dan teater lewat sejumlah ulasan yang termuat dalam majalah 
utama Indonesia, majalah Tempo, pada periode awal abad ke-21 (tahun 2001-2005). Meskipun dibatasi pada satu majalah, resepsi penonton teater di Indonesia cukuplah terwakili karena majalah Tempo terbit setiap minggu dan rubrik teater biasanya terdapat di dalamnya. Pementasan teater sendiri dapat dipantau per minggu. Komuntas pembaca majalah Tempo adalah masyarakat umum menengah sehingga cukup representatif terhadap komunitas pembaca sastra atau penikmat teater Indonesia. Artikel ini membahas temuan penelitian yang terkait dengan judul-judul naskah drama atau judul pementasan teater yang diulas dalam rubrik "Teater" majalah Tempo pada 20012005.

Kelahiran atau awal teater modern Indonesia dimulai jauh sebelum abad ke-20. Embrio teater modern Indonesia berkembang dengan masuknya pengaruh Eropa (Belanda) dalam di Indonesia pada pertengahan abad ke19. Perkembangan atau sejarah teater modern Indonesia sebetulnya diawali oleh Komedi Stamboel pada tahun 1891. Menurut Sumardjo (1992:102), secara garis besar, sejarah teater modern Indonesia terbagi dalam empat periode: (1) masa perintisan teater modern, (2) masa kebangkitan teater modern, (3) masa perkembangan teater modern, dan (4) teater Indonesia mutakhir.

\section{a. Masa Perintisan Teater Modern}

Masa perintisan teater modern ditandai dengan sejumlah ciri teater modern yang membedakannya dengan teater tradisional. Adapun ciri-ciri teater modern yaitu: (1) pertunjukan dilakukan di tempat khusus, (2) penonton harus membayar, (3) fungsinya untuk hiburan, (4) unsur ceritanya berkaitan erat dengan peristiwa sezaman, (5) ungkapan bentuk teater sudah memakai idiom-idiom modern, (6) memakai bahasa Melayu Pasaran, dan (7) adanya pegangan cerita tertulis. Masa perintisan teater modern terbagi pada tiga masa yaitu: (1) masa teater bangsawan, (2) masa Komedi Stamboel, dan (3) masa teater opera.

Pada tahun 1885 Mamak Pushi membentuk rombongan teater berdasarkan properties dan idiom-idiom teater Wayang Parsi. Rombongan ini dinamainya Pushi Indera Bangsawan of Penang. Mula-mula Pushi dan menantunya, Kassim, menempatkan teaternya di rumah-rumah bangsawan yang punya kenduri. Dari sinilah muncul pengertian teater bangsawan. Kehadiran rombongan Indera Bangsawan mendapat sambutan baik masyarakat Melayu, baik di Malaysia, Singapura maupun di Indonesia. Kemudian muncul kelompok-kelompok teater sejenis.

Komedi Stamboel didirikan sekitar tahun 1891 oleh August Mahieu (keturunan Indo-Perancis) kelahiran Surabaya (1860). Komedi Stamboel memperoleh sambutan hangat penontonnya di Surabaya. Kemudian mereka mengadakan pertunjukan keliling Pulau Jawa. Mereka mementaskan lakon-lakon Indonesia (lokal) maupun lakon-lakon asing. Sepeninggal Mahieu (1906) kelompok ini bubar.

Sementara para penerus Komedi Stamboel terus berjalan di masyarakat. Di lingkungan Cina Peranakan di Indonesia juga mulai muncul kegiatan teater. Sekitar tahun 1908 di kalangan Cina Peranakan muncul "Opera Derma". Mereka berpentas untuk kegiatan amal sehingga para pemainnya kebanyakan para amatur.

\section{b. Masa Kebangkitan Teater Modern}

Masa kebangkitan teater modern Indonesia terbagi dalam tiga masa yaitu: (1) masa Miss Riboet's Orion, (2) masa The Malay Opera "Dardanella", dan (3) awal teater modern.

Orion didirikan tahun 1925 oleh T.D. Tio Jr (Tio Tik Djien), seorang pemilik modal yang terpelajar. Rombongan teater Orion telah melakukan beberapa pembaharuan terhadap kelompok-kelompok teater sebelumnya. Pembaharuan yang telah mereka lakukan misalnya: (1) pembagian episode lebih diperingkas, (2) adegan memperkenalkan diri tokoh-tokohnya dihapus, (3) selingan (berupa nyanyian/tarian) di tengah adegan dihapus, (4) sebuah lakon diselesaikan dalam satu malam saja, (5) repertoire cerita mulai banyak cerita- 
cerita asli. Nama Miss Riboet's Orion itu sendiri merupakan gabungan nama dari kelompok ini dan nama bintang primadonanya, yakni Miss Riboet.

Kelompok Dardanella didirikan 21 Juni 1926 oleh A. Piedro (Willy Klimanoff) di Sidoardjo. Mereka terobsesi untuk menyaingi kepopuleran kelompok Orion. Kelompok ini memang akhirnya merajai dunia teater peride 1920-1930-an. Dardanella sangat terkenal terlebih-lebih lagi dengan dimilikinya sejumlah bintang primadonanya seperti: Tan Tjeng Bok yang pintar bermain pedang, Dewi Dja, dan Astaman. Bahkan, tahun 1934 tokoh-tokoh Orion seperti Nyoo Cheong Seng dan istrinya Fifi Young (Tan Kim Nio) menyerberang ke Dardanella. Mereka banyak mementaskan naskah-naskah asli dan naskah asing. Sebelum akhirnya bubar, kelompok ini banyak melakukan pertunjukan di luar negeri. Tidak hanya di negara-negara Asia saja mereka pentas, tetapi juga hingga Eropa dan Amerika.

Awal teater modern mulai berkembang sebetulnya sejak akhir abad XIX hingga sebelum masa pendudukan Jepang. Pada periode ini banyak ditulis naskah drama seperti: Lalakon Raden Beij Soerio Retno (oleh F. Wiggers, 1901), Bebasari (oleh Rustam Effendi, 1926), dan lain-lain. Setelah Dardanella, muncul sejumlah kelompok teater lain, bahkan sampai ke beberapa daerah seperti: Miss Tjitjih (Sunda), Sri Asih, Sandiwara Wargo (Jawa). Selain itu, juga muncul kelompok-kelompok sandiwara amatur yang tidak hanya sekedar mancari penghasilan dari pementasannya.

\section{c. Masa Perkembangan Teater Modern}

Masa perkembangan teater modern terbagi dalam tiga kategori waktu: (1) teater zaman Jepang, (2) teater Indonesia tahun 1950an, dan (3) teater Indonesia tahun 1960-an. Pada zaman Jepang muncul kegiatan teater amatur di samping kegiatan teater profesional yang sudah marak berkembang. Pada periode ini muncul sejumlah kelompok teater profesional dan amatur. Periode ini ditandai dengan adanya campur tangan Jepang terhadap bidang kesenian termasuk dalam perteateran.

Pada masa tahun 1950-an muncul pelopor sandiwara Maya, group-group teater permulaan dan akademi teater. Pada masa inilah muncul zaman emas teater yang pertama. Usmar Ismail bersama Dr. Abu Hanifah membentuk kelompok teater Maya. Naskahnya yang pertama mereka pentaskan berjudul Nusa Laut (karya Usmar Ismail) tanggal $27 \mathrm{Mei}$ 1944. Kemudian diikuti oleh sejumlah pementasan lainnya. Maya boleh jadi merupakan "avantgarde theatre" Indonesia. Kelompok ini merupakan "ayah kandung" dari tradisi teater modern Indonesia selanjutnya. Kemudian pada tahun 1955, Usmar Ismail mendirikan ATNI (Akademi Teater Nasional Indonesia).

Sementara itu di Yogyakarta (1954) muncul ASDRAFI. Juga banyak kelompokkelompok teater lainnya seperti STB (Bandung), Teater Bogor, Studi Grup Drama Djokja, dan sejumlah kelompok teater yang berbasiskan universitas. Pada masa tahun 1960an diwarnai dengan kelanjutan zaman emas teater I, berbagai festival teater, teater keagamaan, organisasi teater nasional dan juga teror Lekra dalam perteateran.

\section{d. Teater Indonesia Mutakhir}

Teater Indonesia mutakhir diawali setelah tahun 1965. Periode ini ditandai dengan adanya Dewan Kesenian Jakarta, sayembara naskah dan terjemahan naskah drama asing, TIM sebagai "pusat pendidikan" teater, isu teater avant garde, dan zaman emas kedua teater Indonesia. Pada periode mutakhir ini sebetulnya terbagi atas masa-masa: 1965-an, 1970-an, 1980-an, dan 1990-an yang masingmasing mempunyai tokoh-tokoh teater (dan nama kelompok teaternya) yang menonjol seperti: Rendra (Bengkel Teater), Arifin C.Noor (Teater Kecil), Putu Wijaya (Teater Mandiri), dan Nano Riantiarno (Teater Koma).

Selain keempat tokoh tersebut masih banyak sejumlah nama yang turut menghiasi perkembangan teater modern Indonesia mutakhir. Ada sejumlah nama seperti: Teguh Karya (Teater Populer), Suyatna Anirun 
(Studiklub Teater Bandung), Ikranegara (Teater Saja), Wahyu Sihombing (Teater Lembaga), Teater Lisendra, Teater Kail, Road Teater, Teater Gelanggang Remaja Jakarta Timur, Art Study Club Jakarta, Teater SAE, Teater Luka, Teater Gandrik, Teater Gapit dan sebagainya. Kelompok-kelompok teater tersebut banyak menampilkan lakon-lakon produksi mereka sendiri, lakon-lakon tradisional yang dikemas secara baru, naskah-naskah asli Indonesia maupun naskah-naskah asing (baik dari Barat maupun Timur).

Berdasarkan temuan hasil penelitian Nurhadi (2003) tentang perkembangan teater pada akhir abad ke-20 (pada tahun 1999), diperoleh sejumlah temuan sebagai berikut. Dari ketiga puluh empat data mengenai teater Indonesia akhir abad XX yang terkumpul, terdapat 17 naskah terjemahan (saduran atau adaptasi), 13 naskah Indonesia dan 4 data tentang kegiatan teater. Naskah asing yang diterjemahkan kebanyakan dari penulis Barat (seperti Bertolt Brecht, Eugene Ionesco, dan lain-lain) dan naskah adaptasi dari Cina.

Dari data yang diperoleh ternyata kotakota atau daerah yang dijadikan pementasan teater adalah Bali, Bandung, Jakarta, Makasar, Padang, Solo, dan Yogyakarta. Yang paling banyak ada di Jakarta yakni di Gedung Kesenian Jakarta, Graha Bhakti Budaya TIM (Taman Ismail Marzuki), Pusat Kebudayaan Perancis, Sasono Langen Budaya TMII (Taman Mini Indonesia Indah), Teater Tanah Airku TMII, dan Teater Utan Kayu. Berikutnya yaitu Yogyakarta yakni di Gedung Societet dan Purna Budaya. Sementara itu, pementasan di Bandung dilakukan di Pusat Kebudayaan Perancis, Selasar Seni Sunaryo, Taman Budaya Jawa Barat, dan Universitas Pasundan.

\section{B. METODE PENELITIAN}

Subjek penelitian ini yaitu artikelartikel ulasan teater yang berupa resensi pada majalah Tempo, tepatnya berupa rubrik teater. Subjek penelitian ini dibatasi sesuai dengan judul penelitian ini, yaitu dari tahun 2001 hingga tahun 2005. Datanya berupa kepingan data CD yang dikeluarkan oleh pihak Tempo.
Pengumpulan data dilakukan dengan cara menyortir semua rubrik teater yang terdapat dalam majalah Tempo edisi 2001-2005. Data-data yang terdapat dalam rubrik tersebut kemudian dikategorikan berdasarkan permasalahan yang telah dirumuskan dalam penelitian ini kemudian dianalisis untuk penulisan sejarah teater Indonesia pada awal abad ke-21.

Dari data-data tersebut kemudian dilakukan pembacaan secara cermat sambil melakukan pencatatan dan pengkategorian terhadap hal-hal yang berkaitan dengan topik tulisan. Pencatatan dilakukan atas sejumlah informasi yang meliputi judul drama yang dipentaskan, kelompok teater yang mementaskannya, lokasi pementasan, dan sejumlah informasi lain yang berhubungan dengan penelitian ini. Informasi lain tersebut meliputi pengarang naskah, sutradara, tanggal pementasan, sumber media yang memuatnya, dan sejumlah keterangan lain.

Untuk validitas data dipergunakan validitas semantis. Untuk reliabilitas data dipergunakan reliabilitas intrarater (dengan cara membaca berulang-ulang) dan reliabilitas interrater (dengan berdiskusi sesama dosen pengampu mata kuliah Kajian Drama Indonesia PBSI, yaitu dengan Dr. Suroso). Analisis datanya dilakukan dengan teknik deskriptif kualitatif.

\section{HAS I L P E NELITIAN DAN PEMBAHASAN}

\section{Hasil Penelitian}

Berdasarkan penelusuran data-data yang dapat dikumpulkan, berikut ini dipaparkan sejumlah temuan penelitian seperti tampak dalam table 1 terlampir.

\section{Pembahasan}

Berdasarkan temuan penelitian seperti yang tertera dalam tabel 1 , setidaknya tercatat sejumlah naskah drama yang telah dipentaskan di Indonesia selama lima tahun abad ke-21. Setidaknya naskah-naskah tersebut yang pementasannya berhasil diliput atau diresensi 
oleh Tempo. Naskah-naskah itu berupa: 11 naskah asing, 7 naskah terjemahan, 8 naskah adaptasi, 29 naskah Indonesia, 2 naskah berbahasa Jawa, dan 7 artikel yang terkait dengan teater tetapi berupa informasi pementasan naskah. Jika jumlah naskah asing, terjemahan, dan adaptasi digabungkan jumlahnya mencapai 26. Jumlah ini hampir sama dengan jumlah naskah asli Indonesia (plus berbahasa Jawa) sehingga perbandingannya 26:31 artikel pemberitaan.

Temuan data ini mengindikasikan kalau Tempo (khususnya dalam orientasi perteaterannya) cukup sebanding dalam mengungkap berita teater nasional dengan teater asing (yang mencakup terjemahan dan adaptasi). Hal ini akan diulas pada bagian pembahasan berikut ini.

\section{a. Pementasan Teater 2001}

Pada tahun 2001 setidaknya ada 14 artikel yang memberitakan atau meresensi pementasan 14 naskah drama. Selain itu terdapat dua artikel yang terkait dengan perteateran yaitu tentang wayang suket dan tentang sutradara Rahman Sabur. Dari keempat belas naskah yang dipentaskan terdapat 8 naskah Indonesia, 4 naskah asing, dan 2 naskah terjemahan. Naskah Indonesia itu antara lain: Ekalaya (karya Ki Sigit Sukasman), Sokrasana Sang Manusia (karya Yanusa Nugroho), Mengapa Kau Culik Anak Kami? (karya Seno Gumira Ajidarma), Tengkorak (tidak tercatat siapa pengarangnya), tentang Pelacur (karya Julius R. Sirayanamual), Donga Dongo (tidak tercatat siapa pengarangnya), Napol atau Napoleon-Napoleon Bonaparte (karya Joko Bibit Santoso), dan Republik Bagong (karya N. Riantiarno).

Republik Bagong karya N. Riantiarno yang sekaligus bertindak sebagai sutradara dipentaskan di Graha Bakti Budaya (TIM) pada 27 April-6 Mei 2001. Naskah ini berkisah tentang tradisi perebutan kekuasaan yang purba sekaligus subtil. Tapi, di tangan N. Riantiarno, sutradara lakon ini, kisah dialirkan melalui beberapa poros yang seperti menempuh jalan masing-masing: Bagong (dimainkan oleh Butet
Kartaredjasa) dengan kisah perjalanannya terusir dari Amarta, Srikandi yang sibuk dengan pembentukan partai perempuan, atau Yudhistira sang Raja yang kehilangan kekuasaan karena korup dan gemar berjudi (Zulkifli, 2001).

Lebih lanjut Zulkifli (2001) menyatakan komentarnya terhadap pementasan ini sebagai berikut. Dari sela-sela panggung yang ramai, Bagong muncul. Si Bungsu Punakawan berbadan gendut dan bermuka lebar itu masih jenaka seperti dulu, meski sedikit tampak murung. "Saya bosan menjadi saksi. Saya ingin menjadi aktor, menjadi pemain," katanya. Bagong yang dikenal dalam wayang versi Jawa biasanya berperan sebagai penanya yang tekun sekaligus penghibur raja. Tapi, tiba-tiba ia ingin masuk ke kancah kekuasaan. Sebuah layar besar bergambar wajah Bagong turun, lampu terang, dan orangorang bernyanyi.

Dari sanalah cerita Republik Bagong yang dipentaskan Teater Koma di Graha Bakti Budaya Taman Ismail Marzuki, Jakarta, dimulai. Sebuah pementasan tiga setengah jam yang latihannya telah dimulai sejak Februari lalu. Republik Bagong memperkuat kesan konsistensi Teater Koma tersebut. Panggung dipenuhi sebuah layar besar yang dibuat mirip jejeran televisi menafsirkan dialog-dialog penting dengan gambar-gambar yang disorot sebuah kamera. Ketika Srikandi menegaskan pentingnya kerja keras agar para perempuan bisa meraih kekuasaan, layar itu menyajikan gambar asap mengepul dari cerobong pabrik, orang-orang yang bekerja, dan tiang bendera yang ditegakkan. Penegasan yang terasa tumpang-tindih.

Napol atau Napoleon-Napoleon Bonaparte karya Joko Bibit Santoso (sekaligus sebagai sutradara) dipentaskan di Teater Utan Kayu, Jakarta oleh Teater Ruang asal Solo. Naskah ini mengisahkan petualangan Napoleon yang diperankan oleh 4 aktor atau pelaku. Dari dialog keempat Napol itulah para penonton disuguhi sajian pertunjukan mengenai sejarah perjuangan dan akhir hidup Napoleon di tempat pembuangannya, Pulau Saint Helena (Danarto, 2001). 
Naskah Donga Dongo merupakan pementasan Teater Kubur di bawah arahan sutradara Dindon W.S. yang ditujukan kepada para tuna netra. Mereka berkeliling di enam panti pendidikan orang buta di Jakarta. Sambutan para orang buta beragam. Sebelumnya, aktor-aktor Teater Kubur dikenal getol mengeksplorasi tubuh bertolak dari properti "keras" seperti tong bekas, kursi seng, dan jebolan besi beton. Trilogi Besi, pentasnya setahun silam, yang menggabungkan tiga sandiwaranya, Sirkus Anjing (1990), Tombol 13 (1994), dan Sandiwara Dol (1998), nonstop dengan improvisasi tubuh yang mengolah kebisingan ketiga materi itu.

Naskah berikutnya berkisah tentang para pelacur karya Julius R. Sirayanamual dan disutradarai oleh Lena Simanjuntak. Ini memang sebuah pertunjukan teater para pelacur. Yayuk bersama 13 kawan lainnya, pelacur asal desa-desa Malang, Kediri, Babat, Ponorogo, Jember mementaskan carut-marut kehidupannya sehari-hari. Naskah digarap Julius R. Sirayanamual, bekas pemimpin umum majalah anak-anak Kawanku yang beralih menjadi aktivis Hotline, sebuah yayasan pemberdayaan pelacur. Selama dua bulan, Lena Simanjuntak, aktivis teater penyadaran, mendampingi. "Saya hanya fasilitator," kata Lena.

Karya berikutnya yang dipentaskan pada tahun 2001 berjudul Tengkorak. Naskah ini dipentaskan oleh Teater Payung Hitam, disutradarai oleh Rahman Sabur di Graha Bakti Budaya Taman Ismail Marzuki dan di Japan Foundations, Jakarta dalam bulan Juli. Drama ini sama sekali tidak menggunakan kata.

Yang perlu dicatat dalam perkembangan perteateran Indonesia pada 2001 ini yaitu pertunjukan drama Mengapa Kau Culik Anak Kami? karya Seno Gumira Ajidarma yang sekaligus menjadi sutradara. Lakon yang dipentaskan di TIM Jakarta (6-8 Agustus) yang berdurasi 75 menit ini sesungguhnya merangkum sebuah peristiwa intim dalam rentang waktu tiga jam, dari pukul 22.00 malam hingga 01.00 dini hari, dan setiap jam sekaligus berfungsi sebagai penanda pergantian babak. Tak ada hal istimewa yang perlu diceritakan lagi di sini, karena seluruh isi percakapan di panggung tak lain hanya sehimpun berita yang telah diketahui umum lewat media massa. Misalnya, pembantaian tahun 1965, ketika bangkai para korban yang bersimbah darah dihanyutkan di kali, atau kesaksian para aktivis korban penculikan tentang bagaimana mereka disiksa: ditutup matanya, digampar, dipaksa tidur di atas balok es, disetrum, supaya mengakui perbuatan yang tak pernah mereka lakukan.

Selain pementasan sejumlah naskah asli Indonesia, selama tahun 2001 ini juga tercatat sejumlah naskah terjemahan yang dipentaskan oleh kelompok teater Indonesia. Kedua naskah terjemahan tersebut berjudul Suara-suara Mati (karya Manuel van Loggem) dan Faust (cerita legendaris asal Jerman yang diindonesiakan oleh Agam Wispi).

Suara-suara Mati yang dipentaskan oleh Actors Unlimited asal Bandung di Pusat Kebudyaan Prancis akhir Maret 2001 ini seperti keluar dari tradisinya sebagai "teater sutradara". Actors Unlimited-kelompok teater terkemuka di Bandung-yang sering dianggap identik dengan induk cikal-bakalnya, yaitu Studiklub Teater Bandung (STB), dikenal dengan realisme dan pola-pola klasiknya. Mereka menyuguhkan karya dramawan Belanda, Manuel van Loggem, berjudul SuaraSuara Mati, di Pusat Kebudayaan Prancis Bandung, akhir Maret silam (dan masih akan dipertunjukkan lagi, karena penonton yang membludak).

Pementasan Faust di Goethe Institut Jakarta merupakan bentuk perayaan ulang Goethe Institut yang ke-40. Pementasan menjelang akhir tahun 2001 oleh Studiklub Teater Bandung kali ini disutradarai oleh Wawan Sofwan. Dalam pementasan ini digambarkan Mephistopheles, setan terkenal itu, berbaju merah. Dari mulutnya meluncur sebuah khotbah. Sedangkan Faust, doktor yang haus segala rahasia ilmu itu, ditampilkan berambut gondrong ubanan, berkarakter gamang. Keduanya dimainkan oleh Ayi Kurnia Iskandar dan Uep Usep Mulyana, para aktor 
muda dari Bandung. Di panggung Goethe Institut Jakarta-sebuah gedung pertunjukan baru yang bakal menyemarakkan kehidupan seni Jakarta-sutradara Wawan Sofwan mengangkat kisah klasik manusia menjual diri pada setan.

Selain 8 naskah asli Indonesia dan 2 naskah terjemahan, selama tahun 2001 Tempo juga mengulas 4 pertunjukan asing. Keempat naskah asing yang dipentaskan di Indonesia itu: (1) Ignis, (2) Antigone (karya Sophocles), (3) Love Letter, (4) Woyzeck.

Ignis dimainkan oleh kelompok teater Double 6 asal Prancis di Teater Luwes, Institut Kesenian Jakarta di bawah arahan sutradara Eric Wurtz pada April 2001. Naskah Antigone karya Sophocles dibawakan oleh kelompok teater asal Yunani, Teater Knosos. Mereka mementaskan naskah klasik Yunani ini di Teater Arena Museum Nasional, Jakarta pada akhir Juni 2001. Naskah ketiga, Love Letter, dipentaskan oleh kelompok teater asal Jepang, Pappa Tarahumara. Pementasan ini disutradarai oleh Hirosi Koike asal Jepang di TIM, Jakarta pada akhir bulan Agustus 2001. Naskah asing keempat juga berasal dari Jepang, meskipun sebenarnya dari naskah terjemahan, Woyzeck, karya George Buchner. Kelompok asal Jepang Black Tent mementaskannya di TIM, Jakarta pada bulan September disutradarai oleh Makoto Sato.

\section{b. Pementasan Teater 2002}

Pada tahun 2002 ada fenomena menarik manakala Tempo tidak memuat artikel pementasan karya asli Indonesia. Dari 18 edisi yang terdata, 4 artikel memuat berita pementasan karya drama asing, 4 drama terjemahan, 3 drama adaptasi atau saduran, 7 artikel lain yang terkait dengan perteateran tetapi tidak secara langsung memberitakan pementasan sebuah naskah tertentu.

Empat artikel tentang pementasan asing itu meliputi: Wayang Boneka Sisilia, Petualangan Penasar, Hamlet, dan Luminescent Twilight. Wayang boneka Sisilia diperankan oleh dalang asal Palermo, Sisilia, Italia bernama Mimmo Cuticchio. Pementasan boneka tradisional Italia (dinamakan dalam bahasa Italia: pupi) yang berusia 200 tahun ini dipentaskan di sejumlah kota di Indonesia, mulai dari Jakarta, Yogyakarta, lalu Bali pada pertengahan bulan Juni 2002.

Petualangan Penasar (La Voyage de Penazar) sebenarnya berasal dari cerita Indonesia klasik tentang Penasar Cenikan atau yang dikenal sebagai Kartala (abdi seorang raja di Bali) yang ditulis oleh Francois Cervantes asal Prancis. Naskah ini kemudian dipentaskan oleh kelompok Compegnie la Enterprise dan disutradarai oleh Cervantes. Pementasan yang berupa monolog ini pernah dipentaskan di dua tempat, di Taman Budaya Surakarta dan di Lembaga Indonesia Prancis pada sekitar akhir Agustus 2002.

Hamlet, naskah klasik karya Shakespeare, dipentaskan oleh gabungan teater Asia di bawah arahan sutradara Ong Keng Sen asal Singapura. Pementasan Hamlet ini dilakukan di negeri yang menjadi latar cerita naskah ini, yakni di Puri Kronborg, Denmark pada 16-23 Agustus 2002. Seorang komponis asal Indonesia, I Wayan Sadra, menjadi salah satu komponis dalam pementasan kolaborasi sutradara kondang asal Singapura ini.

Pementasan asing keempat, Luminescent Twilight, berlangsung di Gedung Kesenian Jakarta dan juga tempat-tempat lain di Indonesia (Jawa-Bali) pada awal Oktober 2002. Luminescent Twilight merupakan koreografi karya Gerad Mosterd, seorang Indo-Belanda (berayah Belanda dan beribu Indonesia). Pementasan ini terinspirasi oleh senja.

Naskah terjemahan yang dipentaskan selama 2002 yaitu: The Vagina Monologues (karya Eve Ensler), Perempuan di Titik Nol (karya Nawal Saadawi), Antigone (karya Sophcles dari terjemahan Jean Anouilh), Romeo dan Juliet (karya Shakespeare). Keempat naskah terjemahan ini masing-masing dipentaskan oleh: Ayu Azhari dkk, Solidaritas Perempuan, Actors Unlimited Bandung, dan Teater Koma.

Terkait dengan pementasan The Vagina Monologues di Indonesia, khususnya di TIM Jakarta, Pareanom (2002) menuliskan 
komentar sebagai berikut. Naskah The Vagina Monologues karya Eve Ensler, yang dipentaskan di Taman Ismail Marzuki, Jakarta, akhir pekan lalu, memang sarat dengan kalimat menggelitik. Contoh menggelitik itu antara lain, pengibaratan vagina seperti Segitiga Bermuda: ada kegelapan begitu pekat dan kerahasiaan yang melilitnya, tak ada yang melapor kembali dari sana.

Masih banyak kalimat lain yang mengundang tawa. Namun, sesungguhnya drama yang disutradarai Jajang C. Noer ini bukan sebuah drama komedi. Sesungguhnya Vagina Monologues adalah sebuah gugatan lantang atas kekerasan terhadap perempuan. Hanya, ia sering memilih jalan berkelok untuk kemudian menghantam di belakang. Misalnya, cerita tentang satu wanita yang dipaksa merasa bersalah oleh pasangannya karena ia orgasme saat bercumbu. Atau, ada juga kisah yang menghantam melalui cerita tentang seorang wanita Bosnia yang mengalami pemerkosaan brutal. Adegan yang dibawakan Ayu Azhari dan Wulan Guritno ini jadi semakin menyentuh disajikan dengan proses pergantian masa lalu dan masa kini. Dulu, vagina wanita adalah desanya yang teduh. Kini, pusakanya bernanah dan rusak berat karena tersodok laras baja senapan (Pareanom, 2002).

Selanjutnya Pareanom menberikan kritikannya terhadap pementasan naskah ini. Menurutnya, pementasan pekan lalu itu terasa monoton dan tersaruk-saruk di beberapa bagian. Membicarakan seksualitas secara blakblakan memang bukan perkara mudah. Soalnya, kultur panjang yang menabukan hal itu tak mungkin diubah secara mendadak. Hal ini terasa di atas dan di bawah panggung. Ketika seorang pemain berteriak lantang tentang vaginanya, ia malah terlihat sangat tidak rileks.

Pemilihan setting yang tidak konsisten-kadang cerita ditarik ke kawasan lokal, tak lagi Amerika-terasa mengganggu.

Vagina Monologues ditulis Ensler pada tahun 1996 setelah ia mewawancarai sekitar 200 wanita. Respondennya dari bocah kencur hingga wanita sepuh, pelbagai profesi serta etnis. Semula, di Amerika Serikat naskah ini nyaris tak bisa dipentaskan karena judulnya yang mengundang perasaan risi. Stasiun radio, misalnya, menolak mengudarakan iklan pertunjukan karena judul ini dianggap porno. Namun, Ensler maju terus dan menolak mengganti titel seperti yang disarankan temantemannya. Begitu ia berhasil menggelar pertunjukan perdana, bisik-bisik si vagina ini tak lagi bisa dibendung. Terle-bih, bintangbintang tenar Hollywood seperti Meryl Streep, Glenn Close, dan Winona Ryder berbondong ingin berpartisipasi.

Edisi akhir tahun Tempo (30/12/20025/1/2003) menceritakan proses latihan dalam rangka pementasan opera La Galigo (naskah klasik asal Bugis) oleh sutradara teater asal Amerika, Robert Wilson. Para aktor Indonesia ini mengadakan latihan di Purwati Center for Art, Bali selama seminggu. Untuk berita ini Tempo menurunkan dua artikel. Artikel pertama tentang latihan di Bali dalam rangka pementasan keliling dunia pada 2004. Artikel kedua berisi wawancara dengan sang sutradara, Robert Wilson.

Dalam artikel ini dijelaskan bagaimana rintangan yang bakal dihadapi drawaman terkenal ini dalam rangka pementasan $\mathrm{La}$ Galigo. Lelaki kelahiran 1941 di Waco, Texas, ini mendengar kabar tentang banyak orang Indonesia yang ditolak visa masuknya ke Amerika. Tapi ia bersikukuh akan memboyong para pemain La Galigo-semuanya warga Indonesia-berkeliling Amerika untuk mementaskan karyanya kelak.

\section{c. Pementasan Teater 2003}

Berbeda dengan tahun sebelumnya, pada tahun 2003 Tempo lebih banyak menurunkan berita tentang teater Indonesia dibandingkan dengan teater asing. Ada 9 artikel tentang pementasan yang berasal dari naskah asli Indonesia, lainnya berupa 3 artikel tentang pementasan adaptasi, 1 artikel terjemahan, 1 artikel berbahasa Jawa, dan 1 artikel tentang tokoh teater Jemek Supardi. Tidak ada artikel yang membahas tentang pementasan kelompok asing di Indonesia pada tahun ini. 
Kesembilan artikel yang membahas pertunjukan naskah asli Indonesia itu meliputi judul-judul sebagai berikut: (1) Waktu Batu: Ritus Seratus Kecemasan dan Wajah Siapa yang Terbelah karya Urogan Prasad, Gunawan Maryanto, dan Andri Nurlatif, (2) Celengan Bisma karya Slamet Gundono, (3) Allah yang Palsu karya Kwee Tek Hoay, (4) Oseng-oseng karya Agus Jolly, (5) Opera Kecoa karya Nano Riantiarno, (6) Gerhana Gerhana karya Julius R Siyaramanual, (7) Anak-anak Kegelapan karya Ratna Sarumpaet, (8) Departemen Borok karya Heru Kesawa murti, (9) namaku adam (TANPA HURUF KAPITAL) karya Shinta Febriany.

Naskah Waktu Batu: Ritus Seratus Kecemasan dan Wajah Siapa yang Terbelah karya Urogan Prasad, Gunawan Maryanto, dan Andri Nurlatif dipentaskan oleh kelompok Teater Garasi disutradarai oleh Yudi Ahmad Tadjudin. Pementasan Teater Garasi asal Yogya ini berlangsung pada 17-18 Maret di Gedung Kesenian Jakarta. Pertunjukan dibuka dengan menampilkan penderita skizofrenia: seorang laki-laki yang terus berteriak di atas ranjang rumah sakit. Skizofrenia bisa dipahami sebagai situasi ketika orientasi ruang-waktu seseorang kacau mengacak, berbenturan satu sama lain. Akibatnya, muncul rasa terasing, takut, dan cemas kelewat takaran.

Para pemain muncul dengan aneka persoalan: kadang sama, kadang berbeda. Ada kalanya suatu kalimat panjang diucapkan oleh dua orang atau lebih, tak dalam waktu yang persis sama, tak tumpang-tindih. Dalam situasi ini, penonton seperti tengah disuguhi sejumlah persoalan serentak, dan semuanya menuntut perhatian. Terasa bahwa berbagai kepingan yang membentuk sosok-sosok manusia yang bergerak dalam ruang-ruang itu-kadang sekadar melintas-terbentuk dari kepingan kecemasan dan ketakutan.

Sebagaimana pertunjukan sebelumnya, Waktu Batu. Kisah-Kisah yang Bertemu di Ruang Tunggu (Yogyakarta, Juli 2002), pertunjukan kali ini pun menurut Dipayana (2003) berangkat dari beberapa mitologi Jawa, yaitu Watugunung, yang diyakini sebagai manusia Jawa pertama; Murwakala, yang merupakan kisah kelahiran Batara Kala; dan Sudamala, yang bercerita tentang kutukan Siwa atas istrinya sehingga berubah wujud menjadi Batari Durga.

Kisah-kisah itu memiliki kesejajaran dengan persepsi orang Jawa (atau kawasan Nusantara pada umumnya) tentang waktu. Waktu itu ancaman: menandai perubahan, yang menuntut mereka menyesuaikan diri, beraktualisasi terhadap perubahan. Dan ketika telaah retrospektif dilanjutkan pada teks kesejarahan, semakin jelas perubahan itu, yakni datangnya orang-orang asing yang membuat mereka terpaksa mengubah wajah budaya sendiri agar selaras dengan budaya pendatang. Dimulai dari kedatangan orang Hindu, Islam, kolonialisme Belanda, hingga neoimperialisme ala Amerika (Dipayana, 2003).

Celengan Bisma karya Slamet Gundono berkisah tentang sepasang ayam dari gerabah- jago Bhisma dan babon Amba. Bermula dari sebuah sayembara, ketika Resi Bhisma berhasil memboyong Dewi Amba lalu menikahinya. Namun, pada malam pertama, Bhisma menolak meneteskan sari kehidupan. Ia ingat janji tak akan menyetubuhi wanita. Bhisma meninggalkan Amba dan pergi mengembara.

Allah Jang Palsoe ditulis Kwee Tek Hoay (1886-1952) dalam bentuk drama komedi enam babak pada 1919. Sebelumnya ia menulis novel pertama Yoshuko Ochida atau Pembalesannja Satoe Prampoean Japan, yang terbit bersambung dalam mingguan $\mathrm{Ho}$ Po di Bogor pada 1905. Pada 1926 Kwee, yang sudah menulis buku sejak remaja, menelurkan lakon Korbannja Kong Ek. Drama ini terbit bersambung di harian Sin Bin. Setahun kemudian ia menelurkan novel Boenga Roos dari Tjikembang. Novel yang memikat dan laris ini dicetak ulang tiga kali pada 1927, 1930, dan 1963. Dan dua kali difilmkan, pada 1931 oleh Wong Brothers dan pada 1976 oleh Fred Young.

Naskah drama Allah Jang Palsoe karya Kwee Tek Hoay, sastrawan keturunan Cina, dipentaskan. Sajian perdana Mainteater Jakarta dengan beberapa keterbatasan sebagaimana 
ditulis oleh Arjanto (2003) dalam artikelnya yang berjudul "Keserakahan yang (Pasti) Tenggelam".

Naskah berikutnya yaitu Oseng-oseng karya Agus Jolly, seniman keturunan Indonesia-Swiss yang berlangsung di Galeri Cipta III Taman Ismail Marzuki, Jakarta. Pertunjukan ini merupakan salah satu bentuk pentas teater multidimensi, sebuah lakon gadogado komedi satire yang ringan.

Menurut Arjanto (2003a), ide Osengoseng berawal dari pengamatan Agus Jolly atas kondisi politik yang bergerak cepat sejak 1998. Semula naskah drama pendek, tapi berubah total setelah dirinya bertemu dengan Bernhard Batschelet, 46 tahun, pada Februari lalu. Solois flute kelahiran Basel, Swiss, yang suka bereksperimen ini memasukkan banyak sekali ide, sehingga kolaborasi itu menjadi lakon gado-gado: musik, miniteater, dan instalasi visual.

Pada tanggal 4-19 Juli, Teater Koma kembali mementaskan lakon Opera Kecoa karya Nano Riantiarno di Gedung Kesenian Jakarta yang dulu sempat dilarang penguasa Orde Baru. Opera Kecoa bercerita tentang orang-orang pinggiran yang tak lebih mujur ketimbang kecoa. Mereka yang ada di goronggorong, di selokan, di gubuk-gubuk jorok, juga di gang-gang pelacuran yang seronok.

Zaman berubah, tapi Teater Koma tetap teguh memeluk resep lama: tari-nyanyiomong-ketawa. Dan seperti 18 tahun silam, para penonton yang kali ini mengeluarkan $\mathrm{Rp}$ 20 ribu hingga $\mathrm{Rp} 75$ ribu untuk tiket masuk itu terguncang dan terkekeh. Ada suara solo seorang Salim Bungsu atau Idris Pulungan yang-boleh jadi-tidak cukup merdu untuk dinikmati. Tapi humor, banyolan bermuatan parodi yang mendekatkan panggung dengan kenyataan sehari-hari di republik ini, untuk kesekian kalinya berhasil mendudukkan Opera Kecoa sebagai sebuah pertunjukan yang menghibur dan instan. Instan? Memang ada pesan-pesan sosial, tapi itulah jenis pesan yang lekas tertiup angin setelah penonton mengayunkan kakinya meninggalkan gedung pertunjukan (Chamim, 2003).
Naskah Gerhana Gerhana karya Julius R. Siyaramanual dimainkan oleh Teater Berdaya di Ruang Goethe, Jakarta. Teater Berdaya adalah sebuah teater beranggotakan para pelacur dari kompleks Bangunsari dan Tambak Asri, Surabaya. Mereka tampil di Jakarta, menyuarakan persoalan trafficking, penjualan wanita.

Naskah Anak-anak Kegelapan dipentaskan oleh Teater Satu Merah Panggung di Graha Bakti Budaya (TIM) pada awal bulan September. Naskah ini ditulis oleh Ratna Sarumpaet yang juga bertindak sebagai sutradara dalam pementasannya. Dahana (2003) menilainya sebagai drama tanpa konteks yang menjelaskan.

Naskah berikutnya yang dibahas dalam rubrik Teater majalah Tempo pada 2003 yaitu Departemen Bobrok. Naskah ini ditulis oleh Heru Kesawamurti dan dipentaskan oleh Teater Gandrik di bawah arahan sutradara Whani Darmawan dan Jujuk Prabowo. Teater Gandrik setidaknya mementaskan naskah ini di Teater Arena Taman Budaya, Surakarta (3-4/10/2003) dan di Gedung Kesenian "Societet", Yogyakarta (5/10/2003). Naskah ini berkisah tentang para koruptor yang blingsatan ketika diperiksa KAK (Komite Anti Korupsi).

Naskah namaku adam (TANPA HURUF KAPITL) menampilkan "rekoleksirekoleksi tentang lelaki yang saya dapatkan di sekitar mata dan hati saya." Penderitaan dihadapinya, namun bukan dalam bentuk perlawanan, melainkan sekadar seruan. Dengan kata lain, soal yang dihadapi bukan masalah perseteruan antara jenis kelamin yang berbeda, tapi sebuah rumah yang terbuat dari tepung dan mentega yang meluluri seluruh kehidupan lakilaki dan perempuan. Maka persoalan dibuka dengan paparan bagaikan reportase rumah tangga keseharian yang saling mengenal satu dengan lainnya, dan terasa akrab. Dan dengan itu pula isu gender tidak kita rasakan dipolitisasi, dan tanpa pula berpretensi menjadi pahlawan.

Selain ke-9 naskah tersebut, selama tahun 2003 Tempo juga menurunkan artikel tentang tiga teater saduran (Ekstrim karya 
William Mastrosimone, God is a D.J karya Falk Richter, Musuh Masyarakat karya Hendrik Ibsen), satu naskah pentas terjemahan (Selawat Barzanji), satu naskah pentas berbahasa Jawa (Leng karya Bambang Widoyo Sp) dan sebuah artikel yang membahas kiprah Jemek Supardi dalam kiprahnya di dunia pantomim Indonesia. Artikel ini ditulis dalam rangka ulang tahun Jemek yang ke-50.

\section{d. Pementasan Teater 2004}

Pada tahun 2004 Tempo setidaknya menuliskan tiga artikel tentang pementasan naskah Indonesia, dua artikel tentang naskah asing, dan tiga artikel khusus yang terkait dengan proses pementasan La Galigo, pesta monolog, dan festival teater realis.

Naskah Zoom karya Putu Wijaya dipentaskan oleh Teater Mandiri di Graha Bakti Budaya (TIM) pada 14-15 Mei 2004. Pementasan Zoom yang juga disutradarai Putu ini berlangsung relatif singkat, hanya 47 menit. Menurut Dahana (2004), dalam pementasan Teater Mandiri kali banyak penonton yang tidak siap menghadapinya. Hal itu cukup pantas karena memang Putu dianggapnya juga tidak "mengistimewakan" manusia.

Sejak awal teater Putu memang tidak mengedepankan karakter atau penokohan yang kuat sebagaimana teater realis atau konvensional. Drama-drama awalnya, Lho, Entah, dan Nol, hingga Aib dan Wah, memperlihatkan posisi manusia yang begitu minor di hadapan satu kekuatan lain yang gergasi dan gigantik. Ini berlanjut pada periode mutakhir Putu dan Mandiri, saat $\mathrm{Yel}$ dipentaskan pada 1990 hingga ke empat kota Amerika Serikat.

Kekuatan gergasi dan gigantik itu ia wujudkan dalam bentuk layar besar yang memenuhi panggung, dan manusia (serta entitas hidup lainnya) hanya muncul sebagai w(b)ayang di layar itu. Gigantisme ini (yang berangkat dari mitos raksasa menakutkan di masa kecil Putu) seperti menyeret manusia, peran, dan eksistensinya ke dalam dimensi atau maqam spiritual yang lain. Tampaknya, bagi Putu, manusia memang melulu fana, wayang kecil, yang mencoba menutupi realitas dahsyat di baliknya. Dalam Zoom Putu kali ini, kita seperti memperbesar lensa batin kita untuk melihat bahwa manusia sesungguhnya tidak berdaya.

Naskah berikutnya yaitu Republik Togog karya Nano Riantiarno yang sekaligus juga menjadi sutradara dalam pementasan Teater Koma di Gedung Kesenian Jakarta pada 28 Juli-6 Agustus 2004.

Republik Togog, kisah yang diambil dari carangan, Sudamala, berisi riwayat Pandawa yang harus menumbalkan Sadewa, si bungsu, untuk keselamatan Kerajaan Amartapura. Namun ternyata itu melulu akalakalan Betari Durga, yang melakukan konspirasi tak sengaja dengan Togog, spion Kerajaan Gilingwesi, untuk bisa menguasai Amartapura. Durga (yang diprotes intelektual muda Hindu Dharma karena digolongkan setan/rakseksi), melalui asistennya Kalkali, merasuki jiwa Samiaji, sulung Pandawa, dan Togog melakukan penghasutan, mengendalikan takhta.

Naskah Waktu Batu 3: Deux ex Machina dan Perasaan-perasaanku Padamu yang dipentaskan Teater Garasi di Graha Bakti Budaya (TIM) dalam rangka art summit IV merupakan karya Urogan Prasad, Gunawan Maryanto dan Andri Nurlatif. Pementasan naskah ini disutradarai oleh Yudi Ahmad Tadjudin. Menurut Utari (2004), pementasan Teater Garasi merupakan pendobrakan konvensi teater yang menggelisahkan penonton.

Lebih lanjut Utari (2004) mengomentari pementasan teater asal Yogyakarta ini dengan sejumlah gambaran sebagai berikut. Pada akhir pertunjukan layar putih terangkat ke atas memperlihatkan aksi panggung band Melancholic Bitch. Sambil merokok, sang vokalis melantunkan lagu $M y$ Feeling for You yang diciptakannya sendiri. Suaranya tak terdengar jelas, tenggelam oleh teriakan seorang lelaki bersayap berdaster putih. "Aku masih cantik, kan, Suster, anakku saja tak henti-henti mencium tubuhku. Di dekat kandang kijang, ia mengawiniku," ujar lelaki itu. 
Kemunculan band itu telah menahbiskan klimaks. Akhir manis yang menenteramkan pementasan Waktu Batu 3: Deux ex Machina dan Perasaan-Perasaanku Padamu oleh Teater Garasi di minggu ketiga acara Art Summit IV. Bertempat di Graha Bhakti Budaya, kelompok teater dari Yogyakarta ini memanggungkan versi akhir naskah Waktu Batu, yang dimulai sejak 2001.

Tak ada perubahan teks yang berarti di bagian ketiga ini. Keberangkatan cerita ini masih bersumber pada tiga tema: waktu, manusia, dan identitas. Di dalamnya, tergumpal mitologi tentang ketiga tema itu. Tentang Watugunung, bocah yang menikahi ibunya; Murwakala, yang lahir dari persetubuhan Siwa dan Uma yang gagal; dan Sudamala, kunci untuk mengembalikan Durga menjadi Uma. Tiga mitologi itu berkumpar dengan kegelisahan zaman baru yang muncul bersama kedatangan bangsa asing di Nusantara.

Artikel lain yang dituangkan Tempo pada tahun 2004 ini yaitu dua pementasan naskah asing dan kelompok teater asing di Indonesia. Yang pertama dari Mesir dan yang kedua dari Jepang. Firmansyah (2004) dalam artikelnya menyatakan bahwa pementasan Aqnea Aqmesha wa Massaer (Topeng, Baju, dan Nasib) oleh Teater El Hanager, Mesir, di Graha Bhakti Budaya TIM, Jakarta, pertengahan September itu pintar mengusik batin. Ia mengajak penonton menyelami setiap adegan yang merangkum kelahiran dan kematian. Aqnea Aqmesha wa Massaer pertunjukan yang ritmis, tapi lakon yang disutradarai Hani el-Mettenawy ini tak membuahkan bosan, tak membuat dahi terus berkerut.

Dalam pementasan Aruku selama 20 menit, kelompok teater DA.M asal Jepang menghadirkan kepekatan adegan berjalan yang dilakukan Hijiri Yaegashi, Ayumi Imai, Ikumi Ohashi, dan Akihiro Nakajima. Akankah perjalanan mereka berakhir? Pertanyaan itu terus melekat di benak penonton hingga lagu Somewhere Over the Rainbow milik Judy Garland di film Wizard of $O z$ itu lenyap. Mereka terus berjalan di atas empat jalur dalam garis bujur sangkar di tengah panggung.

Inilah ketidakpastian, suatu situasi yang menantang penonton untuk mengikuti perjalanan tak berujung dalam pementasan Aruku. Di Graha Bhakti Budaya, kelompok teater DA.M dari Jepang mendedahkan gagasan tentang nilai filosofi Aruku (berjalan) di acara Art Summit IV, pertengahan September 2004 silam.

Disutradarai Hiroshi Ohashi, pertunjukan berdurasi satu setengah jam ini mayoritas diisi gerak. Dialog dalam bahasa Jepang lebih banyak berisi racauan seorang perempuan di bagian tengah pertunjukan. Duduk di atas kursi, ia mengoceh banyak hal. Sebagian menceritakan situasi saat ia memutuskan berhenti makan tomat, merujuk pada lakon When we stop eating tomatoes, yang mereka mainkan di Festival Asia Meets Asia di Jepang (2001) dan Laokoon Summer Festival di Hamburg, Jerman (2002)

Menurut Utari (2004a) Aruku adalah sebuah anti-estetik yang diciptakan Ohashi dengan semangat eksperimental yang kuat. Ia tak peduli karyanya terlihat banal atau mentah. Baginya, bentuk inilah yang mampu menyuarakan lingkaran situasi kekerasan, ketakutan, kegelisahan, dan hasrat dalam hidup manusia.

Informasi lain yang diberitakan Tempo dalam rubrik teater tahun 2004 yaitu tentang pesta monolog dan festival teater realis serta proses pementasan naskah Bugis, La Galigo, oleh Robert Wilson.

Pesta monolog yang dipentaskan di Teater Kecil TIM, Jakarta pada 8-16 Mei 2004 tersebut melibatkan 18 aktor dari 11 kota Indonesia. Kedelapan belas aktor tersebut: (a) Adi Kurdi, (b) Chaerul Umam, (c) Putu Wijaya, (d) Ikranagara, (e) Amak Baljun, (f) Amoroso Katamsi (Teater Kecil), (g) Slamet Rahardjo, (h) Tuti Indra Malaon, (i) Nano Riantiarno, (j) Nanoq da Kansas-Bali, (k) Asep Budiman, (l) Joe Mirshal-Padang, (m) Burhan Folka-Medan, (n) Whani Darmawan-Yogya, (o) Bang ZaidJakarta, (p) Slamet Gundono (Solo), (q) Abdul Rojak-Makassar, (r) Zaenal Abidin Domba atau Mimi Thea. 
Festival teater realis di Graha Bakti Budaya TIM Jakarta di penghujung 2004 diselenggarakan atas inisiatif Dewan Kesenian Jakarta. Festival ini diikuti oleh tujuh kelompok teater dari berbagai kota Indonesia. Semuanya mementaskan lakon-lakon realis. Ketujuh kelompok teater tersebut: (a) Teater Populer: Pakaian dan Kepalsuan (Achdiat Kartamihardja) oleh Slamet Raharjo: 4 pemain; (b) STB: Nyanyian Angsa (Anton Chekov); (c) Teater Makasar: Hantu-hantu (Ibsen); (d) Teater Aristokrat Jakarta: Polisi (Slawomir Mrozek); (e) Komunitas Satu Kosong Delapan, Denpasar: Matinya Pedagang Keliling (Arthur Miller); (f) Teater Gidag Gidig, Solo: Dag Dig Dug (Putu Wijaya); (g) Teater Gapit, Solo: Mainan Kaca (Tennessee Williams).

Artikel terakhir yaitu tentang proses pementasan La Galigo yang pada edisi sebelumnya pernah dibicarakan. Pementasan La Galigo merupakan fenomena tersendiri karena naskah Bugis ini dipentaskan keliling dunia oleh sutradara teater kondang asal Amerika, Robert Wilson.

Pertunjukan perdana La Galigo di gedung teater utama Esplanade, Singapura ini banyak dinantikan orang -terutama masyarakat kesenian Indonesia. Ada nama besar Robert Wilson dan pilihannya untuk mengangkat $L a$ Galigo, sebuah mitologi Bugis yang di Sulawesi Selatan sendiri telah lama dilupakan. Juga keputusannya melibatkan lebih dari 50 aktor dan penari muda-yang rata-rata selama ini tidak dikenal-dari Sulawesi, Papua, Jawa, dan Bali. Berikut ini paparan Suyono (2004) tentang proses pementasan La Galigo.

Pertunjukan yang bakal menyusuri Singapura, Amsterdam, Barcelona, Italia, dan New York ini sesungguhnya hanya melalui tiga kali pertemuan: dua kali latihan, Desember 2002 dan September 2003, di Purnati Art Center, Batuan, Bali, masing-masing dua minggu, dan terakhir tiga minggu menjelang pementasan di Singapura. Sangat singkat, dan itu menimbulkan pertanyaan tentang kesiapan para pemain. Apalagi Wilson, figur pendobrak opera tradisional itu, pada saat bersamaan juga memiliki produksi-produksi lain. Ketika latihan pertama di Bali, misalnya, ia baru saja tiba dari Paris, mengurusi pertunjukannya yang terganggu oleh imbauan pemogokan serikat kerja Prancis.

\section{e. Pementasan Teater 2005}

Selama tahun 2005 Tempo hanya memuat informasi 8 pertunjukan teater, 6 naskah karya Indonesia dan 2 naskah adaptasi. Keenam naskah Indonesia itu berjudul: (1) Matinya Seorang Pejuang: a Tribute to Munir) karya FX Rudy Gunawan, (2) Maaf Maaf Maaf karya Nano Riantiarno, (3) Sobrat karya Arthur S. Nalan, (4) Jangan Menangis Indonesia karya Putu Wijaya, (5) Tanda Cinta karya Nano Riantiarno, dan (6) Repertoar Hujan karya Gunawan Maryanto.

Naskah Matinya Seorang Pejuang: a Tribute to Munir) karya FX Rudy Gunawan memang dipentaskan guna mengenang kematian Munir. Pementasan ini berupa monolog yang dibawakan oleh Whani Darmawan dan disutradarai Landung Simatupang. Dalam komentarnya, Idayanie (2005) mengungkapkan sejumlah hal sebagai berikut. Gedung Societet Taman Budaya Yogyakarta, Kamis (13/1) pekan lalu itu, penuh. Di depan lebih dari 300 pengunjung, Whani memainkan emosi. Lebih-lebih istri Munir, Suciwati, yang menyempatkan diri hadir. Dia terisak dan beberapa kali menyeka air mata. Maklum, kenangan dan emosinya bangkit.

Naskah berikutnya berjudul Maaf Maaf Maaf karya Nano Riantiarno yang sekaligus juga menjadi sutradara dalam pementasan Teater Koma di Graha Bhakti Budaya pada 2-5 Maret 2005. Pementasan ini diselenggarakan dalam rangka perayaan ulang tahun Teater Koma yang ke-28, sebuah pementasan atas naskah pertama mereka yang dicekal Orde Baru. Pementasan Teater Koma kali ini penata musiknya dipegang oleh Embie C. Noer (adik Arifin C. Noer) yang juga bermain sebagai dalang. Inilah pementasan yang dilakukan oleh duo-Cirebon (Nano dan Embie) yang bernuansakan hiasan tarling disko penuh semburan kritik terhadap penguasa (Basral, 2005). 
Selain naskah Maaf Maaf Maaf, Teater Koma pada akhir Juli 2005 juga mementaskan naskah Tanda Cinta, ditulis dan disutradarai oleh Nano Riantiarno. Pementasan Tanda Cinta khusus dimainkan berdua oleh Nano dan Ratna Riantiarno. Dalam pementasan ini Panggung ditata minim-a-lis. Tak me-nunjukkan sebuah ruangan konkret. Dari langit-langit tergantung "hiasan" komposisi segitiga, bujur sangkar, dan bulatan untuk aksen panggung. Kursi-kursi besi didesain dengan bentuk seolah sandarannya melesak. Di situ, sepasang suami-istri tua duduk membicarakan keseharian mereka. Begitulah komentar Suyono (2005) terhadap pementasan Teater Koma kali ini.

Naskah Sobrat karya Arthur S. Nalan dimainkan oleh Bengkel Teater di Graha Bhakti Budaya (TIM) pada akhir Juni 2005. Asa (2005) dalam resensinya menyatakan bahwa lakon Sobrat yang gelap menjadi sebuah tontonan yang menghibur dan manja oleh Rendra. Sobrat bukan sebuah melodrama. Ini dikatakan sendiri oleh Rendra di buku acara. "Saya mementaskannya dalam gaya mendongeng yang ceria, sehingga isinya yang gelap itu akan menonjol sebagai ironi." Tanpa pendekatan seperti itu kiranya lakon Arthur S. Nalan, yang menjadi pemenang sayembara penulisan Dewan Kesenian Jakarta (DKJ) 2003, itu akan lebih susah dikeduk potensi warna lokalnya yang sebenarnya kaya (Rendra menyebutnya jejak teater rakyat dan kandungan etnografi) dan akan hanya menyediakan kesempatan menuturkan cerita lurus yang sedikit berpanjang-panjang, yang hanya akan ditunggu bagaimana semuanya berakhir.

Naskah berikutnya berjudul Jangan Menangis Indonesia. Naskah ini ditulis oleh Putu Wijaya. Dalam pementasannya di Graha Bhakti Budaya (TIM) pada 15-16 Juli 2005, Teater Mandiri di bawah arahan sutradara Putu Wijaya kali termasuk eksperimen penggabungan bahasa visual dan verbal di atas panggung. Putu juga menampilkan dua boneka raksasa (si Bandot) yang telah menjadi bagian teaternya sejak 1971.

Naskah asli terakhir pada tahun 2005 ini berjudul Repertoar Hujan. Naskah garapan
Gunawan Maryanto (juga bertindak sebagai sutradara) ini dipentaskan oleh Teater Garasi di Bentara Budaya Jakarta pada pertengahan November. Sebelumnya naskah ini dipentaskan dalam Physical Theater Festival di Tokyo (11 dan 14 November 2005). Suyono (2005a) meresensi pementasan Teater Garasi di Jakarta dengan komentar sebagai berikut.

Repertoar Hujan adalah karya Teater Garasi yang berangkat dari hal-hal personal. Ini sebuah impresi tentang kesepian dan hujan. Sebuah teater tanpa kata-kata sama sekali. Hanya mengandalkan gerak tubuh yang ingin mengatakan di luar hujan deras-dan di dalam tiba-tiba hasrat melonjak, tubuh bergairah, tapi hambar, penuh luka, penuh keterasingan satu sama lain.

Selain enam naskah asli Indonesia, pada tahun 2005 ini juga dilengkapi dengan dua artikel resensi terhadap pementasan naskah adaptasi: (1) L'Home d'Hus (dari Alkitab atau Kitab Ayub) dan (2) Montserat (karya Immanuel Robles). Naskah pertama dipentaskan menjadi pantomim oleh Camille Boitel di Gedung Kesenian Jakarta akhir Juni. Naskah kedua dipentaskan oleh Teater Lembaga dengan Joseph Ginting bertindak sebagai sutradara, berlangsung di juga di Gedung Kesenian Jakarta dalam bulan Juli.

Montserrat yang berlatarkan pemberontakan di Venezuela adalah lakon yang sarat konflik psikologis dan dilema moral. Seorang kapten Spanyol bernama Montserrat yang pro Bolivar memberikan bocoran kepada sang hero, sehingga ia pun lolos dari penggerebekan. Ia tak mau memberi tahu persembunyian Bolivar. Kolonel Izquerdo, atasannya, menyeret enam orang tanpa salah dan mengancam akan menembaknya satu per satu bila Montserrat tak buka mulut. Begitulah komentar Suyono (2005b) terhadap pementasan ini.

\section{KESIMPULAN}

Berdasarkan uraian di atas dapat disimpulkan hal-hal sebagai berikut. Sesuai dengan catatan dalam rubrik teater majalah Tempo, setidaknya pementasan teater pada 
2001-2005 terdapat: 11 naskah asing, 7 naskah terjemahan, 8 naskah adaptasi, 29 naskah Indonesia, 2 naskah berbahasa Jawa, dan 7 artikel yang masih terkait dengan teater. Jika jumlah naskah asing, terjemahan, dan adaptasi digabungkan jumlahnya mencapai 26. Jumlah ini hampir sama dengan jumlah naskah asli Indonesia (plus berbahasa Jawa) sebanyak 31 naskah, sehingga perbandingannya 26:31 artikel pemberitaan. Temuan data ini mengindikasikan bahwa Tempo (khususnya dalam orientasi perteaterannya) cukup sebanding dalam mengungkap berita teater nasional dengan teater asing (yang juga mencakup naskah terjemahan dan adaptasi).

Te muan ini sebenarnya mengindikasikan bagaimana cita rasa pemerhati teater Indonesia yang dibidik oleh majalah Tempo, majalah umum nasional yang posisinya seringkali ditempatkan sebagai majalah utama Indonesia. Pembaca Tempo dalam menikmati pementasan teater tidak hanya berorientasi pada karya sastra asing semata tetapi juga terhadap karya teater asli Indonesia. Ada suatu kondisi yang cukup berimbang dalam hal perteateran ini yang kemungkinan akan berbeda jika penelitian hal yang sama diterapkan dalam bidang film atau aspek seni budaya lainnya.

\section{DAFTAR PUSTAKA}

Arjanto, Dwi. 2003. "Keserakahan yang (Pasti) Tenggelam," Tempo. Jakarta, 26 Mei. . 2003a. "Semar Betawi di Perjamuan Politik," Tempo. Jakarta, 16 Juni.

Asa, Syu'bah. 2005. "Kekhawatiran Berbuah Kegembiraan," Tempo. Jakarta, 27 Juni.

Basral, Akmal Nasery. 2005. "Saat Duo Cerbon Berpadu," Tempo. Jakarta, 7 Maret.

Chamim, Mardiyah. 2003. "'Opera Kecoa' Pasca-Orde Baru," Tempo. Jakarta, 14 Juli.
Dahana, Radhar Panca. 2003. "Mikrofon yang Berteriak," Tempo. Jakarta: 29 September.

2004. "Manusia dalam Zoom Putu," Tempo. Jakarta, 24 Mei. 2001. "Napoleon dari Solo," Tempo. Jakarta, 14 Mei.

Dipayana, Ags. Arya. 2003. "Bangsa tanpa Wajah Budaya," Tempo. Jakarta, 24 Maret.

Firmansyah, Arif. 2004. "Bahasa Topeng, Bahasa Tombak," Tempo. Jakarta, 20 September.

Idayanie, L.N. 2005. "Renungan untuk Pejuang,” Tempo. Jakarta, 17 Januari.

Nurhadi. 2003. "Perkembangan Teater Indonesia pada Akhir Abad XX,", Jurnal Imaji, Edisi Agustus 2003.

Pareanom, Yusi A. 2002. "Merayakan Eksistensi Vagina," Tempo. Jakarta, 11 Maret.

Sumardjo, Jakob. 1992. Perkembangan Teater Modern dan Sastra Drama Indonesia. Bandung: PT Citra Aditya Bakti.

Suyono, Seno Joko. 2004. "La Galigo, Kisah Cinta di Singapura," Tempo. Jakarta, 22 Maret.

\section{5. "Pamflet Cinta Nano- Ratna,” Tempo. Jakarta, 1 Agustus. 2005a. "Tafsir Hujan Teater Garasi," Tempo. Jakarta, 21 November. 2005b. "Dilema Batin Montserrat," Tempo. Jakarta, 25 Juli.}

Utari, F. Dewi Ria. 2004. "Mereka yang Mengendapkan Memori," Tempo. Jakarta, 4 Oktober.

Zulkifli, Arif. 2001. "Memelihara Konsistensi Lewat Bagong," Tempo, Jakarta, 30 April. 
Lampiran:

Tabel 1 Judul Naskah yang Dipentaskan di Indonesia dalam Majalah Tempo 2001-2005

\begin{tabular}{|c|c|c|c|c|}
\hline No & Tahun & Judul Naskah & Pengarang & Keterangan \\
\hline 1 & \multirow[t]{14}{*}{2001} & Faust & Agam Wispi & terjemahan \\
\hline 2 & & Ekalaya & Ki Sigit Sukasman & \\
\hline 3 & & Sokrasana Sang Manusia & Yanusa Nugroho & \\
\hline 4 & & Woyzeck & George Buchner & $\begin{array}{l}\text { terjemahan-asing } \\
\text { (Jepang) }\end{array}$ \\
\hline 5 & & Love Letter & - & asing (Jepang) \\
\hline 6 & & Mengapa Kau Culik Anak Kami? & Seno Gumira Ajidarma & \\
\hline 7 & & Tengkorak & - & \\
\hline 8 & & Ttg kehidupan pelacur & Julius R. Sirayanamual & \\
\hline 9 & & Danga Dongo & - & \\
\hline 10 & & Antigone & Sophocles & asing (Yunani) \\
\hline 11 & & $\begin{array}{l}\text { Napol (Napoleon-Napoleon } \\
\text { Bonaparte) }\end{array}$ & Joko Bibit Santoso & \\
\hline 12 & & Republik Bagong & N. Riantiarno & \\
\hline 13 & & Ignis & - & asing (Prancis) \\
\hline 14 & & Suara-suara Mati & Manuel van Loggem & terjemahan \\
\hline 15 & \multirow[t]{14}{*}{2002} & Romeo dan Juliet & W. Shakespeare & terjemahan \\
\hline 16 & & Ttg monolog & $\begin{array}{l}\text { (Whani Darmawan; } \\
\text { hari lain Patrick } \\
\text { Reynard, Edi Sutardi) }\end{array}$ & \\
\hline 17 & & Luminescent Twilight & Gerad Mosterd & $\begin{array}{l}\text { asing, Indo-Belanda; } \\
\text { keliling Jawa-Bali }\end{array}$ \\
\hline 18 & & Gitawerta Saijah dan Adinda & Multatuli & adaptasi \\
\hline 19 & & Luka & $\begin{array}{l}\text { Kuo Pao Kun } \\
\text { (Singapura) }\end{array}$ & $\begin{array}{l}\text { adptasi The Coffin is } \\
\text { Too Big for the Hole }\end{array}$ \\
\hline 20 & & Antigone & Jean Anouilh & terjemahan \\
\hline 21 & & Hamlet & Shakespeare & $\begin{array}{l}\text { (bxirbgagai } \\
\text { negara) }\end{array}$ \\
\hline 22 & & Petualangan Penasar & $\begin{array}{l}\text { Francois Cervantes } \\
\text { (Prancis) }\end{array}$ & asing (Prancis) \\
\hline 23 & & Wayang Boneka Sisilia & Mimmo Cuticchio & asing (Italia) \\
\hline 24 & & Mas Tom & Henry Fielding & adaptasi \\
\hline 25 & & Serat Cebolek & Naskah Jawa & bahasa Jawa \\
\hline 26 & & Perempuan di Titik Nol & Nawal Saadawi & terjemahan \\
\hline 27 & & Dalam kantong Plastik & - & \\
\hline 28 & & The Vagina Monolog & Eve Ensler & terjemahan \\
\hline 29 & \multirow[t]{12}{*}{2003} & $\begin{array}{l}\text { namaku adam (TANPA HURUF } \\
\text { KAPITAL) }\end{array}$ & Shinta Febriany & \\
\hline 30 & & Departemen Borok & Heru Kesawa Murti & \\
\hline 31 & & Anak-anak Kegelapan & Ratna Sarumpaet & \\
\hline 32 & & Musuh Masyarakat & Henrik Ibsen & adaptasi \\
\hline 33 & & Gerhana Gerhana & Julius R. Siyaramanual & \\
\hline 34 & & Leng & Bambang Widoyo Sp. & bahasa Jawa \\
\hline 35 & & Opera Kecoa & Nano Riantiarno & \\
\hline 36 & & Oseng-oseng & Agus Jolly & \\
\hline 37 & & Selawat Barzanji & Syu'bah Asa & terjemahan \\
\hline 38 & & Allah yang Palsu & Kwee Tek Hoay & \\
\hline 39 & & Celengan Bhisma & Slamet Gundono & \\
\hline 40 & & God is a D.J. & Falk Richter & adaptasi \\
\hline
\end{tabular}

Pementasan Teater Indonesia 2001—2005 (Analisis Rubrik Teater Majalah Tempo) (Nurhadi) 


\begin{tabular}{|c|c|c|c|c|}
\hline 41 & & $\begin{array}{l}\text { Waktu Batu: Ritus Seratus } \\
\text { Kecemasan dan Wajah Siapa } \\
\text { yang Terbelah }\end{array}$ & $\begin{array}{l}\text { Ugoran Prasad, } \\
\text { Gunawan Maryanto, } \\
\text { Andri Nurlatif } \\
\end{array}$ & \\
\hline 42 & & Ttg pentas pantomim & & $\begin{array}{lr}\text { utk memperingati } \\
\text { ultah ke-50 Jemek } \\
\text { Supardi }\end{array}$ \\
\hline 43 & & Ekstrim & William Mastrosimone & adaptasi \\
\hline 44 & \multirow[t]{8}{*}{2004} & Festival Teater Realis & & \\
\hline 45 & & $\begin{array}{l}\text { Waktu Batu 3: Deux ex Machina } \\
\text { dan Perasaan-perasaanku Padamu }\end{array}$ & $\begin{array}{l}\text { Ugoran Prasad, } \\
\text { Gunawan Maryanto, } \\
\text { Andri Nurlatif }\end{array}$ & \\
\hline 46 & & Aruku & - & asing (Jepang) \\
\hline 47 & & Agnea Aqmesha wa Massaer & Kassem Muhammad & asing (Mesir) \\
\hline 48 & & Republik Togog & Nano Riantiarno & \\
\hline 49 & & Zoom & Putu Wijaya & \\
\hline 50 & & Pesta Monolog & $\begin{array}{l}18 \text { aktor dari } 11 \text { kota } \\
\text { Indonesia }\end{array}$ & \\
\hline 51 & & La Galigo & Rhoda Grauer & $\begin{array}{l}\text { asing (adaptasi dari } \\
\text { Bugis) }\end{array}$ \\
\hline 52 & \multirow[t]{8}{*}{2005} & Repertoar Hujan & Gunawan Maryanto & \\
\hline 53 & & Tanda Cinta & Nano Riantiarno & \\
\hline 54 & & Montserrat & Immanuel Robles & adaptasi \\
\hline 55 & & Jangan Menangis Indonesia & Putu Wijaya & \\
\hline 56 & & L'Home d'Hus & Alkitab (kitab Ayub) & adaptasi \\
\hline 57 & & Sobrat & Arthur S. Nalan & \\
\hline 58 & & Maaf Maaf Maaf & Nano Riantiarno & \\
\hline 59 & & $\begin{array}{l}\text { Matinya Seorang Pejuang (a } \\
\text { tribute to Munir }\end{array}$ & FX Rudy Gunawan & \\
\hline
\end{tabular}

